\title{
Enhancing the Role of Civil Society Organizations in the Fight against Corruption in Nigeria
}

\author{
Surajo Yahaya Muhammad \\ School of Continuing Education (SCE), Bayero University, Kano (BUK), Nigeria \\ mjsuraj09@gmail.com
}

\begin{abstract}
To ensure the attainment of good governance and sustainable development, corruption and its scourge must be combated. In Nigeria, the state has had series of anti-corruption measures by successive administrations in its 55 years of existence as an independent entity. While such measures appeared to have been well packaged, however, absence of political will and inability of the state to regard civil society organizations as important partner in the anti corruption has retarded the country's ability to get rid of the menace of corruption, hence the inability of Nigerian state to provide effective and efficient services to its teeming populace. Being a partner in the development process of modern state, and in order to effectively enhance their roles in the fight against corruption, the paper proper ways upon which civil society groups can organize themselves and work with the state to get rid of corruption in the country.
\end{abstract}

Keywords: Civil Society, Corruption, Democracy, Democratization, State

\section{Introduction}

There has been contending views regarding the basis that led to the emergence of corruption in Nigeria. While one perspective had it that it can be traced back to the period of pre-colonial Nigerian society, the other is of the view that the period of colonialism was actually the epoch upon which corruption found its way in to Nigeria's political environment. Upholding the foregoing, Yusuf (2014) asserts that, our indigenous tradition [in pre-colonial period] is one that is big on free exchange of gifts to signify acceptance and cordiality. However, many times, such gestures may be extended as inducement, for instance, to an 'Oba' or 'Obi' or 'Emir' to exercise discretion in the giver's favour. But such situations were more of an aberration than the norm. Thus, corruption in that era was in its infancy. This means that such practices were more of a gesture and appreciation than inducement. On the latter, Chika (2013) argued that, embedding corruption as a norm was the work of colonialism because they enjoy no right and had no moral basis in the tradition, convention and or myth of Nigerian pre-colonial societies to rule over them, as it was only done on conquest by force of arms. This is why it is strongly believed that one of the greatest legacies the imperialists transferred to Nigeria at Independence was corruption, since the imperialists could not have transferred a better title than they themselves possessed. The preceding perspective clearly showed that, in addition to the practice of exchange of gesture as obtained in the pre-colonial Nigeria, it is the illegal occupation of our societies by colonial masters and imposition of their ill conceived policies that made corruption took its root and germinated in to Nigeria's governance process.

Because of the seriousness of the problems and threats pose by corruption, civil society organizations have, being an actor in the development process, long before independence, continues to provide veritable platforms for citizens to engage Nigerian state on policy issues for the common good of all. Though, even with the Nigeria's endorsement and ratification of UN Convention Against Corruption (UNCAC) ${ }^{1}$ in 2004 and African Union Convention on Preventing and Combating Corruption (AUCPCC) ${ }^{2}$ in 2003 coupled with the fact that, the state has had series of anti-corruption measures in its 55 years of existence as an independent entity, and while such measures may appear to be well packaged and conceptualized, absence of political will, genuine commitment and government's failure to regard civil society organizations as partner in the development process has continue to impede efforts meant to combat corruption and its scourge in the country, hence the failure of government to provide effective and efficient services to its teeming populace. It is against the forgoing tied with the fact that there are also the challenges and problems bedevilling civil society organizations in their fight against corruption that, this study, examines the role played by such groups in the past and present, the challenges and problems they encountered, and proper ways in which the roles would be enhanced.

\footnotetext{
${ }^{1}$ See UN Convention Against Corruption (UNCAC), 2004.

${ }^{2}$ See African Union Convention on Preventing and Combating Corruption (AUCPCC) in 2003
} 


\section{Conceptual Clarifications}

For the purpose of conceptual clarity of the study, the following concepts are defined as follows:

Civil Society: Social science concepts are not simple and unambiguous one because scholars have, using their spectacles, viewed them from different perspectives. The concept of civil society also suffers from the same trend. It is seen as a collection of institutions and other no-state groups who articulate the interests of not only their members but the society in general, moulding and constraining state power. Such groups most times determine the accountability of government by approving or disapproving what goes in to it. In the same vein, it is seen as;

...an opposite of despotism, a space in which several groups could exist and move something to ensure softer and more tolerable condition of existence (John hall as cited in Kukah, 1999:43).

This means that civil society organizations constitute a social force in a society who complements the state and also where necessary query state policies for the betterment of all. Also, Agnelli, designate civil society as;

...the meeting of autonomous subjects of the state and its institutions, united not only by values and cultures but also by the desire to act conjointly and to assume specific responsibilities in projects of general interest (in Helmich and Lemmers (1998) cited in Nwosu (2006).

In other words, civil society is seen as an array of varied civil associations working in different areas of interests and are tied and united by common values and goals working to improve the life of humanity. Moreover, another perspective is that of 'policy prescription perspective' which its proponents argued that civil society in Africa only emerged out of the 'good governance discourse' of the 1980s and 1990s spearheaded by western donor institutions such as the World Bank, International Monetary Fund (IMF). The discourse, as Wendy (2008: 4) observed, saw Washington consensus which emerged in the 1990s prescribed a reduction in the role of state and increased role of civil society in the development process. Thus, civil society emerged primarily as a product of policy prescription to improve the performance of states in Africa. Though, scholars of African studies such as Mamdani (1999: 13), kicked against it on the basis of the fact that it assumed that Africa did not have civil society. To sum it all however, this paper sees civil society as an array of varied institutions, organizations and behaviour situated between the state, the business world, and the family working to influence the state for the common good of all. Such groups may be pressure based or interests focused.

Corruption: While the phenomena of corruption is both local and international because it exist both in the developed and developing countries, its magnitude and intensity differs from one country to the other. Like other social concepts, the concept of corruption has also been interpreted from different perspectives. It has been seen to mean;

...more than public officers taking bribes and gratification, committing fraud and stealing funds and assets entrusted to their care. Corruption... means the deliberated violations, for gainful ends, of standards of conduct, legally, professionally, or even ethically established, in private and public affairs. These gains may be in cash, or, kind, or it may even be psychological, or, political, but they are made from the violation of the integrity of an entity and involves the subversion of its quality and capacity (Bala, 2008 in Mahmud, 2014: 2).

From the forgoing therefore, it is apparent that corruption is not only about the exchange of bribe and or gratification for personnel gain but also violation of the ethical standards and laws set to guide public conducts. It is also a multi dimensional concept cutting across all aspects of human endeavour which can be political, economic, social, religious, and even cultural, to mention a few, in so far as it involves action either by individual or organizational that lead to inducement of behaviour, and or breach of law, for private gain. For the purpose of this study therefore, corruption is conceived as any act or acts by public officials, and or politicians, that amounts to abuse of the power entrusted to them for personal gain. Such acts may take the form of bribe, inflation of contracts, diversion of resources, fraud, rigging of election, etc. To sum them all in view of problems and threats pose by corruption, civil society, being an array of autonomous associations working to influence government and its policies for the betterment of all, is not only an important partner in the anti-corruption crusade but one whose role is critical and indispensable in getting rid of corruption in human society. 
Review and Theorizing the link between Civil Society and Corruption: Assumptions and counter assumptions always exist when it comes to defining what constitute a particular social phenomenon. The incidence of corruption is not an exception. While several explanations exist on the emergence and growing intensity of corruption in Nigeria, this study adopts the 'state capture theory of politics' in its discourse. According to the theory, capture means a group or social strata in a society that seizes decisive influence over state institutions and policies at the expense of the interests of generality of people. Corroborating this position, Nemanja (2006) explains that;

It is the 'seizure of laws to the advantage of corporate business through influential political links in the parliament and government. When the state is captured in this manner, the whole legal system becomes the opposite of what it should be, because it works to the advantage of illegal interests that are dressed up in a legal form (in Vesna, 2007: 1).

Also, Onuoha (2009) added further that;

Literally, to capture means the act of seizing by force or getting possession of something by superior power of stratagem. Essentially, in political science, capture is said to occur when bureaucrats or politicians who are supposed to be acting in public interest, end up acting systematically to favour particular vested interests (in Mahmud, 2014: 8).

The theory assumed that the capture of state is inevitable in a situation where by a network of corrupt politicians and business executives exist in a society, and such network enjoy the support of the bureaucrats. Consequently, in that kind of situation, laws and policies of the state are made only to serve the interests of such network of elites. While describing the network, Ihonvbere (1999) cited in Ojukwu and Shopeju (2010: 16) argued that, these network of elites lacking strong and viable base in production, turns the state as its primary instrument of primitive accumulation, to the extent that the state is mangled and rendered impotent in the quest for nationhood, growth and development, much less democracy. The theory is important because it clearly depict the crises that engulfed Nigerian state where certain 'vested interests' such as the subsidy cabals who continue to influence its governance process to their own ill-conceived agenda, hence the subsequent impoverishment of Nigerians through diversion of government properties, fraud, inflation of contracts, to mention a few, which thus was what provide the foundational basis for contestation between the state and civil society groups being a key stakeholder, in its own right, in the development process of modern state. Therefore, civil society, being an actor in the development process, and considering the menace posed by corruption, is sine qua non to the sustenance of any nation's development.

\section{Methodology}

In view of the above, and in order to have a clear understanding in to the roles played and the challenges encountered by civil society organizations in the fight against corruption in Nigeria in the past, the study utilizes secondary data through survey of journals and literature relevant to the subject matter of the study. The researcher, being an actor in the anti-corruption campaign of civil society organizations, also make use of observation method being a technique that provides a researcher with the chance to immerse into the study of people he/she is not too different from in order to obtain first hand information from such situation.

\section{Discussion on Civil Society in the Fight against Corruption in Nigeria}

Civil society organizations have been in existence even before the advent of colonialism to Nigeria, and have, in their own respective ways, been complimenting the leadership of Nigeria's pre-colonial societies to the extent that the boundary between them and the state is difficult to define. While affirming the above assertion, Habu (2010: 14) argued that, such groups took the form of corporative associations, secret societies, age grades, and the Yan gayyas - self help groups, and their existence has a long history and is a clear evidence to the fact that associational life sprung and shaped the direction of social groups in both social and productive economic activities long before colonization. This means that it is this kind of groups that laid the foundation for the emergence of contemporary civil society as we call them today. Because corruption was at its infancy during this period, such groups were assertive and non-confrontational. With the subsequent forceful and illegitimate capture of Nigerian state by the colonial masters coupled with the abolishment of 'slave trade' with 'legitimate trade', and imposition of repressive and exploitative political and 
economic policies, a more radical and confrontation civil associations were forced to emerge against the colonial state. Such groups include among others; the Cocoa Producers Association (CPA), Nigerian Farmers Union (NFU), Nigerian Railway Union (NRU), National Union of Teachers (NUT), Trade Union Congress of Nigeria (TUCN). In order to suppress the groups in their quest to end colonialism, the colonial government in pursuance of the Public Order Ordinance limit the right to assembly by stipulating that, any meeting that exceed five people, must have Police permit. As a result, Ukase and Bem (2015: 176) asserts that, several people were killed by the Police during the Aba Women's protest of 1929. The riots led by women in the provinces of Calabar and Owerri in south-eastern Nigeria in November and December of 1929, against the policies imposed by British colonial administrators, such protest became a historic example of feminist anticolonial protest. Despite the various attempts by the colonial government to restrain the radical anti-colonial spirits of the civil groups, Muntaqa (2011: 12) observed further that, many of them continue to emerge up to the extent of forging a united front under the auspices of Trade Union Congress of Nigeria (TUCN) in 1942 which later embark on a general strike against the corrupt and ill-conceived policies of the Nigerian colonial state. It was this radical spirit and ability to come together by the civil society groups that serve as a prelude to Nigeria's independence of 1960.

Moreover, at independence in 1960, the colonizers were replaced by what Jega (1993: 99) called a band of political and economic wrecking crews who cared little about democracy and democratic values... rather merely motivated by their selfish interests of acquiring wealth than laying solid foundation for the emergence and sustenance of popular democracy in the country. According to Jega (1993), they even threatened the survival of the nation as one sovereign entity in their determined struggles to acquire more power and wealth, or protect what they have already acquired. It is only the struggle of some concerned Nigerians through working class unions and professional associations that forced ruling class to concede some democratic reforms even though state power was used to advanced selfish ends and execute unpopular and undemocratic decisions. One of such decisions, as observed by Ukase and Bem (2015: 177), was the signing of Anglo-Nigeria Defence Pact. Until its abrogation in 1962, it was generally held that the Defence Pact was a part of a master plan by Britain to preserve her political and economic influence in Nigeria having illegimately ruled the country in a very hostile and exploitative way. This means that, instead of the Nigeria's political leadership of the early 1960s to lay a foundation for the entrenchment of responsive and transparent democratic governance in the country, they instead exhibited similar attitude as their colonial counterparts, and that laid the basis for confrontation between the state and civil associations in the country leading to the first ever nationwide strike in 1964 and which consequently exposed civil society to political prominence and one whose role is critical to the survival of Nigeria's state.

The period of 1966 to the 70s saw the intrusion of military in to Nigeria's governance process characterised by suspension of the constitution, measures were also imposed to suppress the growing radical spirits of civil society organizations such as enactment of the obnoxious Decree No. 53 in 1969 by the Gowon administration which banned associational life and assembly. Thus, the civil society organizations resorted to forging united front to check the excesses of the state in order to ensure the entrenchment of democracy, equality and a just society for the benefit of all. One of such fronts was the formation of United Committee of Central Labour Organizations (UCCLO) under the leadership of Comrade Imoudu. It was the aftermath of such encounter that increased government's attention on the activities of civil society organizations particularly the labour unions that have been legendary in terms of providing other groups with the platform to prevent the state from monopolizing the society. Hence, the formation of one central labour union called the Nigeria Labour Congress (NLC) in 1975 purposely for the state to find it easy in managing civil society organizations. And worthy of mentioning also is the fact that, the result of the confrontation between the state and civil society, was the establishment of the Murtala/Obasanjo Jaji declaration to fight corruption and drew up a time table to return the country to democracy in 1979 , the promise of which was fulfilled.

Even with the ushering in of Nigeria's second republic under a democratically elected government of Shehu Shagari (1979 - 1983), Politicians engaged in high level corruption coupled with the government's tattered way of handling its challenges. Thus, in the light of allegations of corruption and rising high standard of living, workers mobilized and embark on a general strike in 1981 which necessitated the Shagari administration to set up the Ethical Revolution to tackle corruption. Affirming the preceding assertion, Ukase and Bem (2015: 179) added that, Second Republic generally witnessed some hike in the cost of living as a result of 
government's shabby agricultural, economic and industrial policies... resulting from the flamboyant life style and profligacy of the politicians who turned into importers of essential commodities overnight. Hence, the collapse of Nigeria's Second Republic. Though, the Buhari led military administration is seeing to be the most disciplined and committed in trying to get rid of corruption through its policy of War Against Indiscipline (WAI), however, it is also adjudged to be very suppressive and unreceptive to civil society organizations, and at the same time abusive to peoples' fundamental right to association and assembly. In the course of consolidating and legitimizing its regime, the Buhari regime suffered the loss of support of Nigerians, in particular, organized labour including the student unions and the press. This loss of support came on the heels of the obnoxious Decree 4, which was anti-press and anti-freedom of information. Also, the down-sizing of the workers, especially in the civil service gave pressure groups to stand up against the regime (Ibid).

The epoch of 1984 to the mid 1990s was a period in which state - society relations is considered as unprecedented in the post-colonial Nigeria because, as Osaghae (1996) argued, it was a period which witnessed a boost in the suffering of people as it brought an end to free education, medical care and even subsidy in agriculture resulting from the implementation of IMF/World Bank doctored Structural Adjustment Program (SAP). While describing the crises of SAP, Adejumobi (2000: 227) recount that, at no time in Nigerian post-colonial history has the level and dimension of socio-economic crises been as profound as under the regime of Structural Adjustment Program (SAP). Virtually, all the social sectors were hard hit, either entering a comatose state or declining substantially in performance. Because of the severity of the hardship posed by SAP coupled with allegations, criticisms and accusations of manipulation and stagemanaging of transition programmes that engulf Babangida and Abacha's administrations respectively, as observed in Ukase and Bem (2015:180), and also the absence of clear and honest commitment in the fight against corruption that characterized the period, hence the resurgence, as observed by Habu (2010: 22), of struggle for democracy by the civil society organizations which ultimately, after the death of Abacha in 1998, made the military led administration of Abdussalami Abubakar to immediately pursue a transition program and handed over power to a democratically elected president in May 1999.

With the return of democracy in May 1999, the atmosphere was greeted with high hope and expectations to the extent that the euphoria can only be compared with the country's independence of October, 1960. The civil society organizations in particular, having struggled to get the prolonged military rule out of the country, saw the return of civilian administration as an opportunity to entrench democracy as well as instil a sense of responsiveness and accountability in Nigeria's governance by getting rid of corruption. Because corruption has eaten deep in to the fabric of Nigerian society, coupled with the pressure forced on the state by both domestic and international civil society groups on the need for the state to genuinely fight corruption, the state, as observed by Ukase and Bem (2015: 184), had to give assurances that the Fourth Republic was born to restore hope, prosperity and confidence in the Nigeria project, and established and enacted the Independent Corrupt Practices and other Related Offences Commission (ICPC) Act 2000 and the Economic and Financial Crimes Commission (EFCC) Act 2002. Apart from these, Obasanjo also established the Nigeria Extractive Industries Transparency Initiatives (NEITI), the Public Procurement Act, the Fiscal Responsibility Act, and Due Process. Obasanjo also introduced e-payment to detect and deter embezzlement and other forms of financial fraud, and established anti-corruption department in some of the federal ministries and parastatals. Former President Obasanjo rounded up his anti- corruption initiatives with the establishment of the Technical Unit on Governance and Anti- corruption Reforms (TUGAR).

However, with all the above measures put in place by Obasanjo, his government lack genuine political will and commitment to allow the anti-corruption agencies wrestle corruption, hence the criticisms that the anticorruption agencies were selective in the anti-corruption crusade under his administration. Because none of Nigeria's successive regimes since independence in 1960 is, as observed by Mahmud (2014: 9 -10), immune of corruption, the reigns of Obasanjo and Jonathan were regarded as the worst and most corrupt in the 55 years of Nigeria's existence. In fact, in the 8 years of Obasanjo administration, a total of N16.447 trillion was shared among the three tiers of government (1999 - 2007), without much to show as dividends of democracy Iyare (2008) cited in Mahmud (2014: 10). This is in the face of many other allegations of corrupt practices and disappearance of huge amount of petro-dollars. Furthermore, and in an attempt to further expose the monumental corruption that permeated Nigeria's governance process in the fourth republic, Habu (2014: 10) observes that, in 2011 alone more than a trillion naira was spent on petroleum subsidy, and in fact, under the 
duo of former Presidents Umaru Musa Yar'aduwa and Good luck Jonathan, corruption further assumed incredible dimension. The then CBN Governor, Malam Sanusi Lamido Sanusi, as observed in Mahmud (2014: 12) declare that, about 49.8 billion dollars were not repatriated by the NNPC in to federation account which led to his controversial suspension as the Governor of Nigeria's Apex Bank.

In response to the endemic corruption that suffocated Nigeria's fourth republic (1999 - May 2015), civil society organizations formed coalitions and networks such as Zero Corruption Coalition (ZCC), Coalition on Budget Tracking (CBT), Transparency in Nigeria (TIN), the Convention on Business Integrity (CBi), and some individual CSOs such as the Publish What You pay, Integrity Watch, and the Independent Advocacy Project as observed in (Mohammed and Moses, 2012, cited in Habu, 2014: 10). Other groups include Citizens United for Peace and Stability (CUPS), etc. Such groups embarked on series of enlightenment campaigns to educate the general public on the menace of corruption and the importance of whistle blowing. Other measures taken by the CSOs include writing petitions to anti-corruption agencies exposing corruption related offences; strike actions, series of legislative-executive advocacy to ensure anti-corruption legislations such as NEITI, Fiscal Responsibility and Procurement Acts, as well as Whistle Blower Protection Bill, and the recent \#No To Social Media Bill campaign, among others, and peaceful protest and demonstrations such as the January 2012 mass outing against fuel subsidy removal nationwide, which in itself is a popular outcry against the endemic corruption in the oil industry.

To sum it all, the foregoing discussion is a gloom predicting the doom of how a network of corrupt politicians, business executives and bureaucrats who, since Nigeria's independence in 1960, captured the state and continue to profit from its economy and consequently render its democracy unviable in pursuit of their selfcentred agenda semblance of primitive accumulation, hence the contestation between the state and civil society groups. In view of the kind of proscription and intimidation the civil society experienced in the hand of the Nigerian state, because of their vibrancy and fearlessness, as observed by Bangura (2012: 80), the state was unable to subdue them. However, this does not mean that the anti-corruption stance of the civil society groups in Nigeria are not without challenges and problems, which if not tackled, the campaign will continue to suffer serious setbacks. In fact, while one may commend the anti-corruption campaign of civil society organizations in Nigeria, it is also fair to assert that such roles have not been very effective and have only been reactive rather than pro-active. This is because of the myriads of challenges and problems bedevilling them. However, civil society organizations promote democratic process in modern societies. This could be seen in various circumstances and situations where the organizations acted vigorously in mobilizing and educating citizens to choose for the right candidate during elections. This is obvious in the case of Nigeria with the return of civilian administration and elections of 1999, 2003, 2007, 2011 and 2015.

Challenges and Problems faced by Civil Society in the Fight against Corruption: By virtue of the space civil groups are occupying being an autonomous sphere of influence in the society, they are faced with the following challenges and problems as observed by Igbuzor (2010), Odey (2012), and Yusuf (2014) respectively, as stated below:

Lack of creative ways of information dissemination by civil society groups made it very difficult for people at the grassroots to easily comprehend the large volume of information in circulation especially on social media on alleged corruption related offences. This has created gap in public knowledge to the extent that a significant number of people are finding it difficult to interpret the available information at their disposal. Had it been such information will be communicated to the public in their own respective mother languages, civil associations would have enjoy the massive support of the disadvantaged majority wallowing poverty.

Funding has been a major challenge in civil society activism in general, and because most of the anticorruption based CSOs don't have independent sources to generate funds internally within them, they are left with no option than to buy in to the funding programs of international donor agencies which thus dislocate them from their original anti-corruption agenda. It also made some of them to buy in to the illusionary philanthropic intervention of some corrupt politicians, business executives and even bureaucrats to carry out their intervention projects, which in itself is seriously aiding the erosion of confidence of such groups in the anti-corruption campaign. Civil society organizations require knowledge, technical skills and method of evidence generation for anti-corruption advocacy. Unfortunately, majority lack the skills to efficiently and 
effectively engage policy makers and political office holders to practically display genuine political will and commitment in the fight against corruption. Hence, the reason behind the uncoordinated and reactionary anti-corruption campaign approach of most civil society groups in Nigeria. Lack of internal democracy and workable accountability and transparency mechanisms in most individual CSOs, networks and coalitions has only succeeded in tarnishing their image, and has generally led to gradual erosion of confidence which the larger civil society have on them. Some CSO executives are so despotic in the way they manage their respective organizations to the extent that, some are only democratic when one looked at the design of their organograms. And because of the way and manner CSOs are expending donor's funds without concrete results to show, the moral base for CSOs in the anti-corruption campaign is being defeated.

Civil society groups are also faced with the challenge of disconnecting themselves with the people that matter most, the grassroots people. Hence, the question on how representatives are CSOs with the constituencies they claim to be representing? The frank way to answer the question is for one to recognize the disconnection that exist and query the over concentration of such groups in the urban areas or cities. Worthy of mentioning is also the uncoordinated anti-corruption approach used by the CSOs and lack of adequate collective solidarity among such groups. This is most noticeable in the area of duplicating anti-corruption campaigns without coordination, and or in the area of evidence generation coupled with slow face in exploiting opportunities particularly within the context of Freedom of Information Act (FOI) that was passed in 2011. Had it been CSOs will exert pressure on the state on FOI, it would have been a different storey by now in view of the fact that, even the anti-corruption agencies lack adequate and genuine sources of information on corruption other than what the insider politicians and investigative journalists provides. Finally, getting government to really fight corruption and the current state of insecurity are also among the factors posing both challenges and problems for CSOs in the fight against corruption in Nigeria. Under the current uncertain security situation, an activist requires unflinching amount of courage to confront politicians in the state on the issue of corruption. Though, the state under the leadership of President Buhari has been making promising policy pronouncements (zero tolerance on corruption) concerning its anti-corruption posture, the CSOs must device means to get the state on board otherwise we will continue to wallow in the ocean of rhetoric without practical genuine commitments. To overcome the challenges and problems mentioned above, see the next section below.

\section{Conclusion}

The study established that, if there is one pressing issue of concern Nigerian state under the present democratic dispensation should squarely deal with, is the menace of corruption, which is the result of the self centred activities of the network of corrupt politicians, business executives and bureaucrats who abuse the responsibility given to them in Nigeria's governance process. In dealing with it, the study argued that civil society organizations, being actor in Nigeria's anti corruption campaign process coupled with the fact that it's a development partner in its own right, need to urgently provide leadership to ensure synergy of efforts among stakeholders in the anti-corruption drive.

Recommendations: Since no one is spared from the menace of corruption perpetrated by the network of corrupt politicians, business executives, and bureaucrats in Nigeria,

- There is the urgent need for civil society groups and labour unions to understand that, unless we forged a united front by forming a multi-stakeholder mass movement against corruption semblance of the January 2012 mass action against Fuel Subsidy Removal (FSR), our dream of having a country that abhor and is free from corruption will remain a nightmare. Such mass-movement will not only be restricted to the elite NGOs and labour unions but also other individuals, students, market women and community based organizations at the grassroots.

- The movement should have a decentralized structure across the states of the federation. This means that, in each state, civil society groups should create a platform that will mobilize and carry along all associations and individuals passionate about anti-corruption advocacy. For instance, during the 2012 fuel subsidy removal mass outing, Lagos had Joint Action Front (JAF) while Kano formed United Front for Good Governance, which succeeded in mobilizing networks, coalitions, students, groups and individuals that exerted pressure against the state unprecedented in the history of popular actions in those states. 
- Moreover, the mass based platforms across the states should have a consultative committee of at least 36 members at the national level to ensure more coordination and collective solidarity at national level. At the state level, each platform should have a general assembly of planning and coordination with all stakeholders whether individual or organizational fully represented, and also sub-committees to handle issues such as evidence generation on corrupt practices at both national and state levels, advocacy, mobilization, media and publicity, and any other area of importance to enhance the anti-corruption drive.

- Aside the above, and as a pre-condition for a successful mass based outing against corruption in the country, the multi-stakeholder platforms must work both at the state and national levels to exert pressure on government to jointly work to come up with an anti-corruption national strategy, and also make the state to commit itself genuinely to the fight against corruption and ensure the full implementation of Freedom of Information (FOI), Fiscal Responsibility and Procurement Acts, and also the passage of Whistle Blower Protection Bill.

- For civil society groups to have credibility and ensure sustainability of the mass based platforms in the anti-corruption crusade across the states, internal democracy and a high sense of responsiveness, transparency and accountability must be seen in the management of the fronts and in relations with the state and the wider civil society.

\section{References}

Adejumobi, S. (2003). Structural Adjustment, Students Movement and Popular Struggle in Nigeria, 1986 1996, in Identity Transformation and Identity Politics under Structural Adjustment in Nigeria, by Attahiru Jega edited, Nordiska Afrika Institute and Centre for Research and Documentation (CRD).

Bangura, Y. (2012). Why Nigeria's Democracy Does Not Work For the Poor, in Organizing for Democracy: Nigeria and Comparative Experiences, by Bjorn Beckman and Y.Z Yau edited, PODSU, AKCDRAT and CRD.

Chika, E. (2013). Origin of Corruption in Africa and the Way Forward, http://nigeriavillagesquare.com/chikaezeanya/origin-of-corruption-in-africa-and-the-wayforward.html

Habu, M. (2010). Civil Society Organizations in Nigeria, the Politics of Struggle for Human Rights, Krafts Books Limited.

Habu, M. (2014). Civil Society and the Quest for Good Governance in Nigeria's Democratisation Process: A Telescopic View of Jonathan's Administration (2007-2014), being a paper delivered at a one day conference on "Democracy, Governance and Accountability in Nigeria," at Bayero University, Kano, May $20^{\text {th }}, 2014$.

Igbuzor, O. (2010). Good Governance and Accountability of Civil Society Organisations in Nigeria, A paper presented at the National Consultation on CSOs Development Effectiveness in the Context of Nigeria, 25th- 27th May, 2010, Abuja, Nigeria.

Jega, A. (1993). Professional Associations and Structural Adjustment, in the Politics of Structural Adjustment Programme in Nigeria, by Adebayo O. Olukoshi edited, James Currey Ltd, London.

Kukah, M. (1999). Democracy and Civil Society in Nigeria, Ibadan Spectrum.

Mamdani, M. (1999). Citizen and Subject: Contemporary Africa and the legacy of late Colonialism. Oxford: James Currey.

Mahmud, M. L. (2014). Corruption and Democratic Governance: The Signature of Nigeria's Fourth Republic, being a paper delivered at a one day conference on "Democracy, Governance and Accountability in Nigeria," at Bayero University, Kano, May $20^{\text {th }}, 2014$.

Muntaqa, Y. A. (2011). Labour and the Politics of Alliance in Nigeria, a paper presented at a Global Labour Movement Conference in South Africa.

Nwosu, B. U. (2006). Civil Society and Electoral Mandate Protection in Southern Nigeria. The International Journal of Not for Profit Law, 9(1).

Ojukwu, 0. 0. \& Shopeju, J. O. (2010). Elite corruption and the culture of primitive accumulation in 21st century Nigeria. International Journal of Peace and Development Studies, 1(2), 15-24, November 2010 Available online at http://www.academicjournals.org/IJPDS ISSN 2141-2677 (C) 2010 Academic Journals 
Odey, A. N. (2012). Civil Society and Democratic Consolidation in Nigeria, Journal of Emerging Trends in Educational and Policy Studies (JETERAPS) 3(1): 61-67 www.jeteraps.chlolarlinkreserch.org

Ukase, U. \& Bem, A. (2015). The Role of Civil Society in the Fight against Corruption in Nigeria's Fourth Republic: Problems, Prospects and the way forward. European Scientific Journal, 11(2), 1857 - 7881.

Vesna, P. (2007). State Capture and Widespread Corruption in Serbia, March 2007, Centre for European Policy Studies (CEPS).

Wendy, W. (2008). Interrogating Public Sphere and Popular Culture as Theoretical Concepts: On their value in African Studies, CODESRIA General Assembly, 2008, Yaounde, Cameroun.

Yusuf, 0. A. (2014). The Role of Civil Society in the Fight against Corruption In Nigeria, being a Lecture Delivered by Yusuf O. Ali Esq; SAN1 at the9th Edition of the Annual Adekunle Kukoyi Memorial Lecture, Organized by the Institution of Nigeria Surveyors, Lagos State Branch. 